\title{
What Drives the Adoption of Climate Change Mitigation Policy? A Dynamic Network Approach to Policy Diffusion
}

\author{
Marlene Kammerer (corresponding author) \\ University of Berne \\ Department of Political Sciences \\ Fabrikstrasse 12 \\ $\mathrm{CH}-3012$ Bern \\ E-Mail: marlene.kammerer@ipw.unibe.ch \\ Fon: +41764842802 \\ ORCID: 0000-0001-6162-6793 \\ Chandreyee Namhata \\ University of Zurich \\ Department of Political Sciences \\ Affolternstrasse 56 \\ $\mathrm{CH}-8050$ Zurich \\ E-Mail: chandreyee.bagchi@pw.uzh.ch \\ Fon: +41446345847
}

Funding. This work was supported by the Swiss National Science Foundation [grant number 137808]

Acknowledgements. We are grateful to Laurence Brandenberger, Paul Wagner, and our anonymous reviewers for supporting this analysis by providing valuable discussion and critique on how to improve this paper. In addition, we thank Markus Schwarzbauer for editing this text.

Abstract. The requirement of bottom-up action from all the countries to deal with climate change makes it necessary to analyze the factors influencing policy adoption. This article contributes to the policy literature by shedding light on the conditions, which incentivize countries to adopt more climate mitigation policies. The theoretical argument builds on the integrated approaches to study policy diffusion, which include both internal and external determinants as explanations for the adoption of policies. While previous applications typically operationalize the latter by regional proximity, this study highlights the added value of network dependencies capturing political and cooperative interactions across countries. The article finds that the adoption of climate policies is a matter of social influence. Countries are more likely to adopt policies if they cooperate with countries that have adopted more climate policies and are in a similar structural position to countries that are active in climate protection. This article is not only an important theoretical contribution to the policy literature but also enriches our methodological and empirical understanding of climate policy diffusion.

Keywords. Climate change, social network analysis, policy diffusion, cooperation, temporal network autocorrelation model 


\section{Introduction}

The importance of domestic policy adoption to alleviate the adverse effects of climate change is a cornerstone of international negotiations. The Paris Agreement of 2015 is the first international treaty in the history of climate change politics where more than 180 countries in the world agreed to act cohesively. Unlike its predecessors, the treaty is based on the principle of self-determination, requiring ambitious national climate protection policies. It hinges completely on voluntary pledges without any provisions for legally binding emission targets. The current pledges made by the countries are barely sufficient to contain temperature rise by 2 degrees Celsius (Du Robiou Pont et al. 2017). Additionally, while the agreement spells out an ambitious target to limit temperature rise to 1.5 degrees Celsius, there are no concrete plans to accomplish this (Spash 2016). It also ignores equity and justice considerations crucial in multilateral processes (Clémençon 2016). Without any top-down commitments in the Paris Agreement, countries taking up ambitious domestic policy interventions to mitigate greenhouse gas (GHG) emissions will determine its success. This brings us to the pertinent question of what exactly motivates a country to adopt climate change mitigation policies.

Countries have little incentive to engage in mitigation since global climate change is a classic 'tragedy of the commons' (Hardin 1968). Investing resources to adopt mitigation policies targeting the reduction of GHG emissions entails providing a global public good with non-excludable benefits. These benefits not only accrue to the country investing in mitigation but also to others. This encourages free-riding behavior, i.e. enjoying the paybacks from other countries' climate protection efforts, while avoiding costly policies themselves. The free-riding incentives decrease the probability of implementing mitigation policies. Notwithstanding the free-riding incentives from others' mitigation action, countries have adopted several national mitigation policies. The GLOBE Climate Legislation Study (2016; 2014) finds that between 2009 and 2014, the number of climate policies adopted almost doubled in the 99 countries they studied. Framing climate change mitigation as a collective action issue and the reason why countries do not adopt mitigation policies offers only a partial explanation for mitigation policy adoption. It is evident that some countries strongly support mitigation commitments while others are more reluctant (Dimitrov 2010). The current literature counteracts the collective action explanation using co-benefits of mitigation policies as an alternative (Dolšak 2009). 
Co-benefits are defined as benefits like the reduction of air pollution, energy security, etc., ensuing locally from the adoption of a climate change mitigation policy ${ }^{1}$ (IPCC 2007). Nonetheless, the generation of co-benefits ${ }^{2}$ does not detract from the fact that the primary motivation of adopting mitigation policies is to reduce GHG emissions globally. Scholars argue that while co-benefits of mitigation can be crucial for policymakers, it is in fact often overlooked in policy design (IPCC, 2007; Jochem \& Madlener, 2003; Nemet, Holloway, \& Meier, 2010). Consequently, we expect that co-benefits from a mitigation policy are insufficient to spur countries to take up large-scale emission reductions. For example, countries like the United States and China are frequently in a deadlock where each waits for the other to take action (Thurston 2013). If co-benefits were so attractive, they would not observe each other's behavior before taking domestic mitigation action. Hence, we are interested in understanding how international relations and the anticipation of how other countries behave, foster or hinder the adoption of climate change mitigation policies.

We offer our perspective on what motivates the adoption of climate policy. In an increasingly interconnected world, countries can easily observe the behavior of other countries. Keeping this in mind, we specifically investigate two main mechanisms: (1) diffusion triggered through interaction and (2) diffusion triggered through interaction similarity. In the context of the first mechanism, we expect that countries more likely innovate policies when they are directly interacting with other countries that have already adopted the respective policies. Since climate change is a global issue, it requires interactions to coordinate and harmonize national policies. To this end, country officials meet, communicate, cooperate, mutually learn, and exchange ideas in various negotiation forums, as well as international organizations. This may stimulate policy adoption back home, since country officials can emulate or learn from the other countries with whom they interacted. Interaction similarity is our second causal mechanism. We expect two countries that are structurally similar in their interactions to other counties to behave in a similar way, because these countries have similar diplomatic relations, meet with the same countries, and exchange information with same countries. On the one hand, these countries face the same kinds of incentives and on the other hand these countries compare themselves with each other. Both of these may lead to the adoption of similar policies.

\footnotetext{
${ }^{1}$ Mitigation policies usually relate to energy demand, supply, transportation, energy efficiency measures, reducing emissions from deforestation and forest degradation in developing countries (REDD+), etc.

${ }^{2}$ See IPCC 2007, Chapter 11 for a more detailed discussion on this issue (https://www.ipcc.ch/publications_and_data/ar4/wg3/en/ch11.html)
} 
Although the policy diffusion literature has emphasized the importance of interactions (Braun, Gilardi 2006; Simmons, Elkins 2004), no research studies on climate policy adoption incorporated political interactions as an explanation for mitigation policy adoption. We address this gap by investigating how cooperative behavior by interconnected countries influences the diffusion of climate policies.

The following two sections of the article present an overview of the developments in the policy diffusion literature and explore the factors influencing climate policy. We explain why the extant literature has not satisfactorily incorporated the issue of country interactions and highlight the advantages of a dynamic network to explore policy diffusion. These sections are succeeded by our analytical approach and research design. Methodologically, our analysis relies on a temporal network autocorrelation model (Leenders, 2002; Leifeld \& Cranmer, 2016). It allows us to disentangle the various factors influencing mitigation policy adoption. These range from internal motives, resources, or constraints of a country and its international relations, over time. By studying cooperative political interactions in the context of the global climate change issue, we demonstrate that the adoption of mitigation policies is a matter of social influence. Our results show that countries are more likely to adopt policies if they interact with other countries that have already adopted climate policies. Countries also tend to behave akin to those in a similar structural position. The results reflect the necessity of integrating country interactions in the study of climate policy adoption and highlight that they are a much more precise proxy of international interactions as they fluctuate over time.

\section{Theoretical Approaches to Policy Diffusion}

The age of globalization and international cooperation has many implications for policymaking. One such implication is that of cross-national policy convergence. It happens when policy choices in one countries can influence the policy choices of other countries (Bennett 1991; Plümper, Schneider 2009). Many scholars empirically analyze this phenomenon (Braun, Gilardi 2006; Meseguer, Gilardi 2009; Gilardi 2005). They evaluate the interconnectedness between international relations and domestic policy innovation in the context of transnational diffusion processes or clustered decision-making. In other words, we can understand diffusion as a 'dispersion or dissemination' (Elkins, Simmons 2005, p. 36) of political practice. Scholars study these processes in a wide range of phenomena like specific policy instruments, institutions, or policy frameworks (cp. Gilardi 2012 for an overview). Rogers $(1983$, p. 6) defines policy diffusion as a 'process by which [policy] innovation is communicated through certain channels over time among members of a social system'. The 
patterns of policy diffusion are often expressed in two levels: the unit of analysis (e.g. countries) and the social structure (e.g. a policy domain) (True, Mintrom 2001). The mechanisms of policy innovation are either due to the internal characteristics of the unit of analysis (e.g. socio-economic conditions) or the 'unit's interaction with others in the broader social system' (True, Mintrom 2001, p. 34).

Research explains policy adoption by internal and external factors or both (Berry, Berry 2007). Internal approaches posit that social, political, and economic factors endemic to a country influence policy adoption rather than the actions of other countries (Canon, Baum 1981; Gray 1973). Over time, scholars challenged the perspective that others' behavior does not affect policy adoption decisions. This led to the emergence of the study of possible external determinants influencing policy adoption. These approaches claim that policy diffusion occurs when the choices made by one government influences another government's decision to adopt a policy innovation (Graham et al. 2013). The external factor considered has been mainly geographic proximity. According to Berry and Berry (1990), if we do not account for similarities between neighboring countries, an omitted variable bias can lead to false evidence of policy diffusion. Drawing from the policy transfer literature, diffusion studies emphasize the mechanisms of social influence, which manifest through coercion, competition, learning, or emulation (Gilardi 2012; Berry, Berry 2007). The common idea behind all these causal mechanisms of policy diffusion is that the adoption of policies in one country affects the behavior of interdependent countries (Braun, Gilardi 2006).

Geographical interdependencies have typically been the mainstay of diffusion studies. Although they are theoretically important, focusing exclusively on them can significantly undermine our understanding of diffusion processes. There is very little reason to believe that in an increasingly interconnected world, policy diffusion can happen only among neighbors. Karch (2007, p. 72) states we need to 'move beyond the focus on the impact of geographic proximity' to explain diffusion. Consequently, some scholars incorporate other factors like external political pressures (Simon and Elkins 2004), common memberships in international institutions (Holzinger, Knill 2005; Volden et al. 2008) and so on. Volden et al. (2008) argue that geographically close states also share common political, economic, and demographic characteristics, which may explain policy diffusion. While it is not unlikely that states learn from their neighbors, they may also learn from policy experiences in other regions of the world (Matissoff and Edwards, 2014). Policy learning and diffusion can also happen when states are imitating 'cultural cohorts, rather than geographical cohorts' (Matisoff, Edwards 2014, p. 798). 
Additionally, they can occur due to structural interdependencies. Structurally interdependent countries are those, which have a relation or connection permitting communication or interaction (Mohrenberg, 2017). The discussions reveal that it is important to take into consideration ties between countries that are not necessarily geographically close.

To understand such structural interdependencies, scholars often integrate a network perspective in their analysis of policy diffusion. This allows the incorporation of numerous connections and dependencies among individual or collective actors, political units, or different organizations (see, for example, Marin, Wellman 2011). A network perspective in studying the diffusion of policies allows us to explicitly integrate interdependencies arising from social interactions of actors in a policy domain. Consequently, scholars across different policy areas have been assimilating a more refined analytical approach to understand these interdependencies, where the behavior of one actor can be dependent on the actions of other actors (Dorussen, Ward 2010). For examples in different policy domains using network analysis to explain policy diffusion, see Chyzh (2016), who studied human rights diffusion via trade networks; Haim (2016), who investigated how a network of international political alliances influence trade flows; and Mohrenberg (2017), who studied the diffusion of foreign trade policies through bilateral trade flows. Our article contributes to and builds on this literature using network analysis to explain policy diffusion in the context of climate policy on the country level.

\section{Determinants of Climate and Environmental Policy Diffusion}

Similar to studies in other policy areas, research on climate or environmental policy explains policy adoption either by policy diffusion between geographically neighboring countries (Matisoff 2008) or due to the influence of international organizations (Oberthür, Tänzer 2002), and/or by internal determinants (Regens 1980). In addition, some studies use integrated approaches of both external and internal determinants to climate or environmental policy diffusion. For example, Dolšak $(2009,2013)$ examines how internal factors (domestic air pollution, the level of income, democracy levels) with external factors (a country's embeddedness in different networks of intergovernmental organizations (IGO)) affect policy diffusion. Her findings show that countries have a particular incentive to implement international climate protection agreements when emission reduction policies generate domestic co-benefits like reduced domestic pollution. Among external factors, Dolšak (2013) finds that the pressures of EU accession and levels of ratification of the Kyoto Protocol in neighboring countries influence climate policy adoption. Biesenbender and Tosun (2014) 
point out that both external (learning from other international organizations) and internal determinants (political preferences) are responsible for environmental policy diffusion.

Important internal determinants are the income of a country, political partisanship, institutional factors, and vulnerability to climate change. With respect to income, Jänicke (2005) claims that more environmental friendly countries are also rich. Conversely, Madden (2014) finds that the relationship between GDP per capita and climate policy adoption is negative, while Bättig and Bernauer (2009) do not find any relationship. Tobin (2017) examines climate policy adoption in developed countries and concludes that climate policy adoption behavior is positively correlated with high income. Also, natural resource rents are a sizeable part of the GDP and can influence the policy behavior of a country. Since climate protection requires that countries reduce their carbon emissions, it should imply a reduction in the use of fossil fuels. Studies, however, find that resource owners do not support mitigation policies that may reduce their incomes derived from the resource use (Eisenack et al. 2012). GHG emissions can be also an important internal determinant of climate policy adoption. Nachmany et al. (2014) state that almost all countries with significantly higher emissions have taken up mitigation policies to reduce GHG emissions. Scholars have also analyzed the relationship between climate change vulnerability and policy adoption, although more so in the context of adaptation ${ }^{3}$ policies rather than mitigation (Massey et al. 2014; Mozumder et al. 2011; Tol et al. 2008). Vulnerable countries have possibly contributed less to climate change and are economically less capable of adopting costly mitigation policies. Dolsâk (2001) states that vulnerability indeed does not have a significant impact on domestic mitigation efforts. Tubi et al. (2012) later reaffirms Dolsâk's (2001) findings. Among internal political factors, partisanship is salient in explaining policy adoption. Left-wing parties are more encouraging of environmental issues and policy adoption (Neumayer 2003; Tobin 2017). More recently, the has been an upsurge in party polarization on climate change issues, with Republican politicians increasingly considering climate change to be fake (Dunlap et al. 2016). Other internal institutional factors like democracy are also essential for environmental (Bättig, Bernauer 2009; Neumayer 2002) and climate mitigation policy adoption (Dolšak (2013).

International or external factors are important in the climate and environmental policy diffusion literature. According to Oberthür and Tänzer (2002, p. 325) examining the process of climate policy diffusion without incorporating the role of international institutions is incomplete and will seem to represent a result of internal factors or 'simple horizontal policy

\footnotetext{
${ }^{3}$ Adaptation is a process by which individuals, communities and countries attempt to deal with the consequences of climate change, usually on a local level (Hasson et al. 2010).
} 
diffusion' alone. Environmental policy is often associated with institutional interlinkages (Knill, Liefferink 2007; Jordan et al. 2005; Knill et al. 2014; Wurzel, Connelly 2011). For instance, EU membership significantly influences climate policy (Jänicke 2005) as well as strong domestic environmental policymaking (Liefferink et al. 2009).

Overall, the literature emphasizes the primary role of internal determinants, and more recently international or external factors, but largely ignore political interactions in their analytical frameworks. Our main argument is that analyzing the process of climate policy diffusion will be incomplete if we do not account for political interactions to coordinate and/or harmonize national climate policies over time and between different pairs of countries. We follow Mohrenberg's (2017) argument that diffusion depends on structural interdependencies due to interaction and communication even in the absence of geographic connection or proximity. Frequent interaction generates patterns of common behavior and/or structures of trust as well as habit, thereby establishing a network of political interactions. Accordingly, a network perspective allows us to integrate the role of interactions in the study of climate policy diffusion. It is imperative to utilize a network perspective, because as an issue area climate policy itself is an interdependent process. Actions by one country may very well have effects on other countries. The principal aim of our research is to assess the extent to which policy adoption is a function of these political interactions between countries, and extend the traditional approaches by including country interactions in the realm of international climate policy.

\section{A Networked Perspective on Climate Policy Diffusion}

We base our analytical framework on two integrated approaches to study policy diffusion. These approaches are the 'unified model of government innovation' by Berry and Berry (1990, 2014, p. 325) and the conceptual framework laid out by Wejnert (2002).

While the Berry and Berry model is convincing on account of its parsimonious and systematic combination of internal as well as external determinants, Wejnert's (2002) framework offers a more detailed operationalization of important components influencing policy diffusion. In particular, Wejnert (2002) also includes social networks as an explanation for the diffusion of policies. She contends that the timing of policy adoptions depends on the 'interaction of social units in a process of communication' (Wejnert 2002, p. 306) and maps out important network mechanisms that influence the behavior of social units.

Our analytical approach combines these two integrated approaches by blending the parsimony of the Berry and Berry model with the richness of the Wejnert framework. In doing 
so, we include dynamically evolving network dependencies as an important external determinant of policy diffusion along with regional proximity and the typical internal determinants as explanatory factors for the adoption of national policies. Hence, we consider the adoption of climate policies of country $i\left(\mathrm{ADOPT}_{i t}\right)$ as a function of internal determinants $\left(I N T_{i t}\right)$ and external determinants $\left(E X T_{i t}\right)$. Internal determinants encompass the countryspecific motivation to tackle the climate change issue $\left(M_{i t}\right)$, the available resources and capacity of a country to implement climate policies $\left(R_{i t}\right)$, as well as already existing policies $\left(\mathrm{ADOPT}_{\mathrm{it}-1}\right)$ that relate to the problem of climate change. External determinants cover longterm or permanent connections between country $i$ and $j$, such as regional proximity (PROX or the common membership in an international and dynamically evolving relationships as they occur when two countries interact to coordinate and harmonize their national climate policies represented as network relations (NET $\mathrm{Tit}_{\mathrm{it}}$ ). Equation 1 summarizes this relationship, where $i$ and $j$ refer to the individual country and $t$ to time.

$$
A D O P T_{i t}=f\left(I N T_{i t}=\left(M_{i t}+R_{i t}+A D O P T_{i t-1}\right)+E X T_{i t}=\left(P R O X_{i j}+N E T_{i j t}\right)\right) \quad \text { Equation } 1
$$

A crucial assumption of the network approach is that the existence and emergence of ties between the units of analysis depend on the existence of other ties (network dependence assumption) and exogenously given actor attributes (social selection assumption). Political events are 'embedded within networks of interdependencies, the so-called 'context' of these phenomena' (Leenders 2002, 21). This means that political actors are responsive to the context by contemplating the behavior of others. The occurrence of specific attributes or behavior therefore depends on these social ties as well as on the distribution of actor-specific characteristics and behavior across the network.

Leenders (2002, p. 26) argues that social influence occurs '(...) when an actor adapts his behavior, attitude, or belief, to the behaviors, attitudes, or beliefs of other actors in the social system'. Whether the influence is intentional or not is irrelevant. The priority is the availability of information about the behavior and attitude of other actors to be able to mutually compare and learn. In our research context, this implies that countries have a higher probability of adopting a mitigation policy when they are interacting (e.g. to coordinate climate policies or harmonize policy approaches) with other countries that have already adopted climate policies. This argument is in line with findings from Bernstein, Cashore (2012) and Kern et al. (2001). The overall policy diffusion literature also widely accepts this claim (Gilardi 2010). Two main processes are at work here - communication and comparison. Communication 'refers to social influence through direct contact between ego and alter' (Leenders 2002, p. 27). Consequently, countries use other countries with which they have direct ties as their frame of 
reference. For the diffusion of climate policies, this entails that countries are more likely to innovate their climate policy when they are directly interacting with other countries that have already adopted climate policies. These interactions may involve diplomatic communications, meetings of country officials, exchange of material and human resources, and so on. This leads to our first hypothesis:

Hypothesis 1: Countries that interact with other countries that have already adopted climate policies should adopt more climate policies.

Comparison with structurally equivalent or similar countries might trigger the adoption of new policies, too (Wejnert 2002). In the process of searching for a 'social identity,' a country ascribes to itself the same characteristics as structurally similar countries and adopts a similar behavior. Research on international conflict supports this claim by showing that countries tend to follow a similar behavior to structurally equivalent alters (Maoz et al. 2006). Abbot and DeViney (1992) in a study on the transnationality of the welfare state make a comparable claim. Countries are structurally equivalent either because they share important socioeconomic, demographic, political, or geographic characteristics or because they inhibit similar social positions in a political network. With respect to the network perspective, structural equivalence can be defined as the tendency to have and create ties with other actors that make similar choices. Thus, countries that interact with the same set of other countries hold a similar structural position and are said to be structurally equivalent. We call this interaction similarity. For the diffusion of climate policies, we expect countries to imitate other countries that are akin to themselves. This is based on the fact that these countries face the same political context and incentives, which may lead to emulation of each other's policy adoption behavior due to mutual learning and comparison. We therefore hypothesize:

Hypothesis 2: A country will more likely adopt a climate policy if structurally equivalent countries also adopt climate policies.

This approach also has its limitations, as it is not possible to solve the 'chicken and egg' problem and disentangle comparison from communication. In principle, however, countries with direct ties could compare themselves with each other and countries with indirect ties could have overlooked the channels of communication. Also, one cannot truly know whether the similarity of two structurally equivalent countries arises from comparison and/or communication. The results of this study are not meant to offer an empirical solution to separate these two distinct but interconnected theoretical concepts. However, it points to the importance of interdependent decision-making in a more general sense. 


\section{Research Design and Data}

Many earlier approaches to study climate policy diffusion processes use neighboring or peer group effects to capture physical or cultural closeness (Dolšak 2009, 2013; Fankhauser et al. 2014). The assumption is that geographical proximity, trade relations, common membership in international organizations, etc. create direct and indirect links between countries that result in social influence. This increases the likelihood of exhibiting similar policy adoption behavior. These applications frequently use an event history analysis (EHA) model. In an EHA, the main dependent variable is the risk of adopting a new policy. The unit of analysis is typically state-years, country-years, city-years, and so on. The problem with this approach is that although EHA models include neighboring effects, they are incapable of appropriately capturing the interdependencies between countries. Analogous to all kinds of linear regression models, in EHA models the observations are by assumption independent from each other. Therefore, arguing that policy adoption is a matter of interdependencies between the countries violates this very assumption.

Gilardi and Füglister (2008) react to this problem by proposing a dyadic approach, in which the dependent variable is coded as 1 when country A makes its policy more similar to country B. According to them, 'the dependent variable does not record policy change or the influence of one state over another but simply indicates an increased similarity in the policies of two states' (Gilardi, Füglister 2008, p. 419). While we acknowledge that this approach is appealing, it is not without certain drawbacks. To begin with, the dependent variable cannot be observed directly and needs to be constructed indirectly. This makes the process of data collection cumbersome and particularly so with geographically large data sets. Secondly, this approach still neglects dependence structures of higher order as imposed by the network context, as dyadic models still assume independency between the dyads (Beck et al. 2006).

Spatial models, in contrast, 'provide ways to test and accommodate various forms of dependence between the observations' (Beck et al. 2006, p. 28). The researcher knows the nature of the dependence structure and thus does not estimate it. It is usually given by what is called the connectivity matrix, usually denoted by W (Neumayer, Plümper 2016), where a typical element $w_{i j}$ has a value of greater than 0 if the observations $i$ and $j$ are connected (diagonals are set to 0 ). In spatial models, the error term $e_{i}$ - best thought of as an omitted or unmeasured variables bias - in the current unit is correlated to the error of other units. Spatial autoregressive models go one step further. The idea is that the dependent variable (here, policy adoption) is affected by the value of the dependent variable in a connected unit. The closer the connection, the greater the effect. Therefore, interpreting the effects of 
independent variables is more difficult than in linear regression models, as the effect involves feedback loops. For example, the effect of vulnerability has an impact on policy adoption in the current country, which then feeds through policy adoption in all other countries (through the connectivity lag) and these feed back to the current country until an equilibrium is reached. Hence, the effects get smaller and smaller with every subsequent round. Temporalspatial models are an extension in that they allow all variables (dependent, independent) and the connectivity matrix to vary over time and include time-lags (Franzese, Hays 2007). Network autocorrelation models use network relations as the connectivity matrix. In contrast to regional proximity, network relations can emerge or dissolve over time. Here, the weaknesses of the geographical approach are overcome. A network operationalization of country relations provides a much more precise reflection of structural interdependencies as they evolve dynamically over time.

For this analysis, we apply a temporal network autocorrelation model that helps us to understand the structure and effect of political interactions on climate policy adoption. Our temporal network autocorrelation model has the general form as presented in Equation $2^{4}$ :

$$
y_{i t}=X \beta_{i t}+\rho_{1} V \gamma_{i t}+\rho_{2} W y_{i t}+\varepsilon_{i t} \quad \text { Equation } 2
$$

In this model, $y_{i t}$ is our dependent variable $\left(\mathrm{ADOPT}_{\mathrm{it}}\right)$ - the adoption of mitigation policies for every country in the dataset at time $t^{5}$ - where $y_{i t}$ is a count variable defined as the number of climate-related policies a country has adopted at time $t$. The first model term captures the set of covariates representing internal characteristics affecting the policy adoption behavior $\left(I N T_{i t}=\left(M_{i t}+R_{i t}+A D O P T_{i t-1}\right)\right)$, where $X$ is a vector of covariates and $\beta$ the respective parameter estimates. The second model term reflects attribute similarity. It is constructed by multiplying the similarity matrix $V$ based on a specific country attribute with the outcome variable $y_{i t}$. The intuition behind this model term is that country i's behavior may be influenced by country $j$ 's behavior if country $i$ and $j$ are similar with respect to this attribute. For example, if country $i$ and $j$ are from the same region they are expected to also show a similar policy adoption behavior. This model terms allows the inclusion of external determinants, like the geographical proximity of two countries $\left(P R O X_{t}\right)$. The third model term hinges on the specification of the network connectivity matrix $W$ at time $t$ (i.e. the network of political, cooperative interactions at time $t$ ) multiplied with the dependent variable $y_{i t}$. This term represents the policy adoption behavior of other actors in the network at time $t$, (NET it).

\footnotetext{
${ }^{4}$ Compare Leenders (2002) for an encompassing presentation of network autocorrelation models.

${ }^{5}$ Compare Equation 1: $\mathrm{ADOPT}_{i t}=f\left(I N T_{i t}=\left(\mathrm{M}_{\mathrm{it}}+\mathrm{R}_{\mathrm{it}}+\mathrm{ADOPT}_{\mathrm{it}-1}\right)+\mathrm{EXT}_{\mathrm{it}}=\left(\mathrm{PROX}_{\mathrm{i}}+\mathrm{NET}_{\mathrm{it}}\right)\right)$
} 
In our model, the specification includes the effect of direct interactions between two countries and the interactions of structural equivalent countries.

\section{Climate policy data $\left(A D O P T_{i t}\right)$}

We base our analysis on the data from the Global Climate Legislation Study of 2015 (Grantham Research Institute, London School of Economics 2016). It captures climate change legislations targeting mitigation and adaptation in 99 countries plus the EU. These countries are collectively responsible for $93 \%$ of the world's emissions. At present, 58 countries in the world have passed framework legislations, which address 'multiple aspects or areas of climate change mitigation or adaptation (or both) in a holistic, overarching manner' (Nachmany et al. 2014, p. 15). ${ }^{6}$ On the other hand, sectoral climate policies only target one sector at a time, like for a law targeting the reduction of GHG emissions. These polices address different emissionintensive sectors, for example, emissions from agriculture, electricity and heat production, industry, or transport, and other climate-relevant sectors such as forestry or buildings.

One problematic aspect in this analysis might be that we do not differentiate between framework legislations that address more than one sector at a time, and policies that are sector-specific. This might lead to an underestimation of the effect of policy diffusion, as some countries have actually adopted several policies in one go. In addition, the policies captured in the Global Climate Study are also quite heterogeneous in terms of the sectors they target. Treating them all as similar might obfuscate different policy diffusion mechanisms being at work at different sectors. Despite this heterogeneity, for all these policies, the main purpose is climate change mitigation. Of course, in different countries, different sectors contribute in different ways to the climate problem and, therefore, adopt different kinds of policies. Yet, their main aim is to reduce GHG emissions, which makes them homogenous in terms of their overall objective but different in their specific design. In addition, in our data set only a handful of countries have just sectoral policies. We, therefore, expect that the underlying heterogeneity will not have a significant impact on our analysis.

A mitigation policy consists of measures to deal with lowering GHG emissions from sectors presented in Figure 1 and is either framework or sectoral legislations. To give an idea about the different kinds of mitigation policies, we provide examples of such mitigation legislations

\footnotetext{
${ }^{6}$ An example of such a flagship or framework law will be Bulgaria's Climate Change Mitigation Act. The act puts forward the principles of state policy for climate change, the rules relating to emissions trading and the modalities for financing green projects Nachmany et al. 2014.
} 
from the world's top three emitters. At present, these are China, the EU, and the United States.

Table 1: Examples of mitigation policies from the World's top three emitters

\begin{tabular}{|c|c|c|c|c|}
\hline COUNTRY & $\begin{array}{l}\text { YEAR OF } \\
\text { LEGISLATION }\end{array}$ & DESCRIPTION & SECTORS TARGETED & DESCRIPTION \\
\hline CHINA & 2014 & $\begin{array}{l}\text { Energy Development } \\
\text { Strategy Action Plan } \\
(2014-2020)\end{array}$ & $\begin{array}{l}\text { Energy Supply, Energy } \\
\text { Demand }\end{array}$ & $\begin{array}{l}\text { This strategy plan } \\
\text { puts forward } \\
\text { energy } \\
\text { conservation as a } \\
\text { priority in the } \\
\text { power, industrial, } \\
\text { building, and } \\
\text { transport sectors }\end{array}$ \\
\hline US & 2005 & Energy Policy Act & $\begin{array}{l}\text { Energy Supply, Energy } \\
\text { Demand, Transportation, } \\
\text { Research and } \\
\text { Development }\end{array}$ & $\begin{array}{l}\text { The Energy Policy } \\
\text { Act (EPA) } \\
\text { addresses energy } \\
\text { production in the } \\
\text { United States }\end{array}$ \\
\hline EU 28 & 2009 & $\begin{array}{l}\text { Clean and energy- } \\
\text { efficient road } \\
\text { transport vehicles } \\
\text { (Directive } \\
\text { 2009/33/EC on the } \\
\text { promotion of clean } \\
\text { and energy-efficient } \\
\text { road transport } \\
\text { vehicles) }\end{array}$ & Transport & $\begin{array}{l}\text { This legislation } \\
\text { promotes the use } \\
\text { of clean and } \\
\text { energy-efficient } \\
\text { road transport } \\
\text { vehicles }\end{array}$ \\
\hline
\end{tabular}

Source: Adapted from Nachmany et al. 2014

For the construction of our dependent variable, we coded mitigation policies as 1 and summed over the different periods. For example, in phase $t_{1}$ if country $X$ adopted two mitigation policies, the policy adoption variable has been coded as 2 for that time period and the same process is repeated for the other time periods as well. Compare Appendix A for the coding of climate policy adoption data and a list of countries.

\section{Operationalizing connectivity through interaction}

In the following, we show how we operationalized interaction and interaction similarity as network connectivity and how we collected the respective network data. For this purpose, we present the POLCLIMATE data set and we introduce two network autocorrelation terms (NETit) that are supposed to measure our two key concepts. The first, interaction, captures 
the direct ties between two countries, i.e. when they are engaged in diplomatic or political events. The second, interaction similarity, measures to what extent two countries are engaged in similar diplomatic or political events.

POLCLIMATE data set on interaction network data

To collect information on country interactions, we have used the POLCLIMATE (Politics on Climate Change) event data set (cp. for more details Author(s), 2016, Hirschi 2008). The original data set is a sequence of daily dyadic political events related to climate change mitigation that occurred between 1995 and 2015. It includes both conflictive and cooperative events between 215 countries and international organizations. For this study, we used a subset of the POLCLIMATE data set that uses cooperative events only and equals the same countries including the EU that are available in the Global Legislation Study (2015). The final subset contains 98 countries including the EU. These countries cover more than $90 \%$ of the political interactions contained in the POLCLIMATE data set.

We focus on cooperative interactions for several reasons. Countries often meet and exchange views and opinions in international negotiation forums. More often than not, they have opposing views but for mutual profitability reasons, they try to cooperate and find a common ground. This can be a precursor to political coordination between countries (Keohane 1984). We argue that these cooperative interactions are a good proxy for international interdependencies in climate politics as they can influence a country's decisions and vary over time. It reflects a completely different aspect of interdependencies in comparison to spatial proximity or other structural similarities. Cooperation between countries can range from something trivial to something significantly important. For example, minor cooperation is when a country makes a critical or appraising comment on another country's reformed policies. Substantial cooperation, on the other hand, is when a country offers to provide financial support or to agree to exchange confidential information. For exact definitions of the types of cooperative and conflictive events, consult Appendix B.

Each cooperative, dyadic event can be understood as a tie in a network of political interactions. A convenient way to display these network relations is to transform the sequence of dyadic, cooperative events into a connectivity matrix that displays the number of all cooperative interactions between any pair of countries. More cooperative interactions imply closer connectivity between two countries. However, collapsing the complete event sequence into a single matrix would result in a significant loss of information. This would occur in particular with regard to possible dependencies between interactions over time. One possible 
option to overcome this problem is to aggregate the dyadic event sequence into time slices. The resulting connectivity matrices display the number of interactions between any pair of countries in the respective phase.

We had to take an important decision with respect to the number and scope of these phases. While a very small number of phases results in a problematic loss of information, an exceedingly large number of phases leads to a zero inflation of the connectivity matrices as not all countries are involved in political events every year. This potentially leads to an underestimation of the effect of political interactions on the adoption of climate policies. To overcome the trade-off between precision and parsimony, we decided to aggregate the dyadic data by four empirically meaningful time phases.

Table 2 presents the phases (consult Appendix C for a detailed description of the periods). The table shows that the phases differ considerably with respect to the number of years they encompass. In this way, the phases reflect the fluctuation in the international awareness to the climate topic. For example, the two brief periods between 2005 and 2007 and 2008 and 2009 have higher numbers of interactions than the other two phases. The international activity and awareness was peaking when countries were negotiating a potential Post Kyoto commitment in the aftermath to the successful Bali summit in 2007. The cooperative ties of each period are summarized in four weighted, connectivity (network) matrices. That is, the cells reflect the number of interactions, which two countries had in phase $T$. If a country did not interact in a period or was not mentioned in the news wire services, it was added to the matrix as a structural zero to ensure an equal number of actors across all periods.

Table 2: Description of phases used in the analysis

\begin{tabular}{l|lllll} 
PHASE & \multicolumn{1}{|c}{ NAME } & PERIOD & $\begin{array}{l}\text { NUMBER OF } \\
\text { INTERACTIONS }\end{array}$ & $\begin{array}{l}\text { NUMBER OF } \\
\text { ACTIVE } \\
\text { COUNTRIES }\end{array}$ & $\begin{array}{l}\text { NUMBER OF } \\
\text { PASSIVE } \\
\text { COUNTRIES }\end{array}$ \\
\hline$T_{1}$ & $\begin{array}{l}\text { Negotiating the Kyoto } \\
\text { Protocol }\end{array}$ & $\begin{array}{l}1995- \\
2004\end{array}$ & 348 & 37 & 53 \\
\hline$T_{2}$ & $\begin{array}{l}\text { Implementing the Kyoto } \\
\text { Protocol }\end{array}$ & $2005-07$ & 358 & 37 & 53 \\
\hline$T_{3}$ & Post Bali Enthusiasm & $2008-09$ & 594 & 40 & 50 \\
\hline$T_{4}$ & $\begin{array}{l}\text { Towards a New } \\
\text { Agreement }\end{array}$ & $2010-15$ & 290 & 39 & 15 \\
\hline TOTAL & & & 1590 & & \\
\hline
\end{tabular}


Cooperative interaction

The policy adoption behavior of directly interacting countries (cooperative interaction) is one of our two main explanatory factors. The related model term captures one form of network autocorrelation (Leifeld \& Cranmer, 2016). The intuition behind these variables is that the policy adoption behavior of country $i$ affects the adoption behavior of country $j$, because they interact. If the value of the autocorrelation variable is significant and positive, countries tend to show similar adoption behavior as compared to the countries with which they frequently interact. We construct the variables by multiplying the weighted network matrices, one matrix for each phase, with the policy adoption variable of the respective phase. The resulting vectors reflect for each country in each phase the level of policy adoption network autocorrelation. The values rise with the number of interactions and policies adopted. Consequently, the variable interprets the policy adoption behavior of other countries in a network perspective. We expect the model parameter to be significant and positive to support hypothesis 1 .

Interaction similarity

To test hypothesis 2 , we use a model term that encompasses the structural similarity of actors in terms of their cooperative interactions (interaction similarity). We consider actors that are similar in their social activity towards other actors to be structurally equivalent (Wasserman, Faust 1994, p. 348). We construct the interaction similarity model term as a similarity matrix based on Euclidian distance, which reflects the structural equivalence of two actors in terms of their cooperative ties. It is then multiplied by the policy adoption variable. We compute this for each of the four networks. Analogous to the interaction variables, the resulting vector reflects the extent to which a country shows similarity in its policy adoption behavior when compared to other structurally equivalent countries. We expect the model parameter to be significant and positive as evidence for hypothesis 2 .

\section{Control variables}

Drawing from the existing literature, we operationalize internal $\left(I N T_{i t}\right)$ and external (EXT it) determinants of policy adoption. The first set of variables reflects the motivation $\left(M_{i t}\right)$ of a country to adopt mitigation policies. For this purpose, we account for vulnerability, the level of per capita $\mathrm{CO}_{2}$ emissions, population size, and the fossil fuel consumption as percentage of overall energy consumption. To measure vulnerability, we utilize the vulnerability component of the ND-GAIN Index since it is comprehensive, covers many countries and is adjusted for 
GDP, reducing our chances of encountering multicollinearity. ${ }^{7}$ This variable covers the average vulnerability of country $i$ and does not vary over time. ${ }^{8}$ We anticipate a negative correlation between high levels of vulnerability and the adoption of mitigation policies. Furthermore, we use per capita $\mathrm{CO}_{2}$ emissions (measured in tons per capita and logged) averaged for each period. We expect that countries with higher levels of $\mathrm{CO}_{2}$ emissions are more likely to introduce mitigation policies. In this vein, we also control for the population of a country, assuming that countries with a higher population emit more $\mathrm{CO}_{2}$. Moreover, for fossil fuels consumption we expect countries with a higher demand for fossil fuels to adopt more climate policies. Lastly, we control for political partisanship with the expectation that left-oriented governments will adopt more mitigation policies. The variable includes information on whether the ruling party of the chief executive is left, right, or center. ${ }^{9}$

The next set of variables reflects the resources $\left(R_{i t}\right)$ available to a country and capacity of a country to adopt climate policies. Firstly, we control for GDP per capita (The World Bank 2017). We expect that countries with more financial resources will introduce more climate policies. This anticipation also comes from the fact that higher growth in GDP is usually associated with higher levels of GHG emissions. We use the Polity2 index to measure the level of democracy of a country (Teorell et al. 2018) and expect that the more democratic a country is the higher will be its rate of policy adoption.

Moreover, existing mitigation policies (ADOPT ${ }_{i t-1}$ ) might be positively correlated with whether a country adopts more mitigation policies. For instance, the existence of flagship laws may encourage countries to adopt more climate change mitigation. An additional motivation provided by existing policies may be due to the fact that countries realize the co-benefits accruing from adopting climate change mitigation policies in the past make them more likely to adopt climate change mitigation policies in the present.

Lastly, we also control for external determinants (EXT $\left.\mathrm{T}_{\mathrm{it}}\right)$. The regional proximity $\left(\mathrm{PROX}_{\mathrm{i}}\right)$ of countries captures neighboring effects. For this purpose, we coded a variable that assigns countries to world regions as defined by the World Bank. In our model, we included the region

\footnotetext{
7 Compare: Notre Dame's Environmental Change Initiative (ND-ECI) (2015). Notre Dame Global Adaptation Index (ND-GAIN) Available online: URL: http://index.gain.org/ranking/vulnerability. The vulnerability component measures the extent to which a country is susceptible to the adverse effects of climate change. Specifically, it captures a country's exposure to climate hazards, its sensitivity to climate impacts, and its adaptive capacity.

${ }^{8}$ Compare Appendix D where we control for time varying vulnerability indicators. The results do not change.

${ }^{9}$ Data on $\mathrm{CO} 2$ emissions, fossil fuel consumption, and party governments are taken from the Quality of Government Standard Dataset 2018 (Teorell et al. 2018).
} 
as a homophily term same region. A significant positive parameter estimate related to this variable would indicate that countries from the same region show similar policy adoption behavior. Table 3 summarizes all variables and their function in the research design.

Table 1: Overview of all variables, their role in the research design, and data source

\begin{tabular}{|c|c|c|c|c|}
\hline MODEL TERMS & $\begin{array}{l}\text { VARIABLE } \\
\text { NAME }\end{array}$ & EXPLANATION & DATA SOURCE & $\begin{array}{l}\text { RESEARCH } \\
\text { DESIGN }\end{array}$ \\
\hline $\begin{array}{l}\text { DEPENDENT } \\
\text { VARIABLE }\end{array}$ & $\begin{array}{l}\text { Policy adoption } \\
\left(\mathrm{ADOPT}_{\text {it }}\right)\end{array}$ & $\begin{array}{l}\text { Number of adopted } \\
\text { climate change mitigation } \\
\text { policies in period } t\end{array}$ & $\begin{array}{l}\text { Global Climate } \\
\text { Legislation Study }\end{array}$ & $\begin{array}{l}\text { Dependent } \\
\text { variable }\end{array}$ \\
\hline \multicolumn{5}{|c|}{ INTERNAL DETERMINANTS } \\
\hline $\begin{array}{l}\text { EXISTING } \\
\text { POLICIES } \\
(\text { ADOPT } \\
\text { IT-1) }\end{array}$ & $\begin{array}{l}\text { Own past policy } \\
\text { adoption } \\
\text { behaviour }\end{array}$ & $\begin{array}{l}\text { Number of adopted } \\
\text { climate change mitigation } \\
\text { policies in period t-1 }\end{array}$ & $\begin{array}{l}\text { Global Climate } \\
\text { Legislation Study }\end{array}$ & $\begin{array}{l}\text { Control } \\
\text { variable }\end{array}$ \\
\hline \multirow[t]{5}{*}{$\begin{array}{l}\text { MOTIVATION } \\
\left(M_{\text {IT }}\right)\end{array}$} & Vulnerability & $\begin{array}{l}\text { Average vulnerability of } \\
\text { country } i \text { towards climate } \\
\text { change risk (averaged } \\
\text { across periods) }\end{array}$ & $\begin{array}{l}\text { ND-GAIN Index } \\
\text { of vulnerability }\end{array}$ & $\begin{array}{l}\text { Control } \\
\text { variable }\end{array}$ \\
\hline & $\begin{array}{l}\mathrm{CO}_{2} \text { emissions } \\
\mathrm{pc}(\mathrm{log})\end{array}$ & $\begin{array}{l}\text { Average per capita } \mathrm{CO}_{2} \\
\text { emissions (tons, logged) in } \\
\text { period t } \\
\text { (average of period) }\end{array}$ & $\begin{array}{l}\text { Quality of } \\
\text { Governance } \\
\text { dataset } 2018\end{array}$ & $\begin{array}{l}\text { Control } \\
\text { variable }\end{array}$ \\
\hline & Population & $\begin{array}{l}\text { Average population } \\
\text { (logged) in period t }\end{array}$ & $\begin{array}{l}\text { Quality of } \\
\text { Governance } \\
\text { dataset } 2018\end{array}$ & $\begin{array}{l}\text { Control } \\
\text { variable }\end{array}$ \\
\hline & $\begin{array}{l}\text { Fossil fuel } \\
\text { consumption }\end{array}$ & $\begin{array}{l}\text { Average fuel consumption } \\
\text { (\% overall energy } \\
\text { consumption) in period t }\end{array}$ & $\begin{array}{l}\text { Quality of } \\
\text { Governance } \\
\text { dataset } 2018\end{array}$ & $\begin{array}{l}\text { Control } \\
\text { variable }\end{array}$ \\
\hline & $\begin{array}{l}\text { Left } \\
\text { Government }\end{array}$ & $\begin{array}{l}\text { Ruling party is left in period } \\
\mathrm{t}\end{array}$ & $\begin{array}{l}\text { Quality of } \\
\text { Governance } \\
\text { dataset } 2018\end{array}$ & $\begin{array}{l}\text { Control } \\
\text { variable }\end{array}$ \\
\hline \multirow[t]{2}{*}{$\begin{array}{l}\text { RESOURCES } \\
\left(R_{/ T}\right)\end{array}$} & $\begin{array}{l}\text { Democracy } \\
\text { level (Polity2) }\end{array}$ & $\begin{array}{l}\text { Average level of democracy } \\
\text { in period } t\end{array}$ & $\begin{array}{l}\text { Quality of } \\
\text { Governance } \\
\text { dataset } 2018\end{array}$ & $\begin{array}{l}\text { Control } \\
\text { variable }\end{array}$ \\
\hline & GDP per capita & $\begin{array}{l}\text { Average GDP per capita } \\
\text { PPP in period } t\end{array}$ & $\begin{array}{l}\text { Quality of } \\
\text { Governance } \\
\text { dataset } 2018\end{array}$ & $\begin{array}{l}\text { Control } \\
\text { variable }\end{array}$ \\
\hline \multicolumn{5}{|c|}{ EXTERNAL DETERMINATS } \\
\hline & $\begin{array}{l}\text { Cooperative } \\
\text { interactions }\end{array}$ & $\begin{array}{l}\text { Adoption behaviour of } \\
\text { directly linked countries }\end{array}$ & $\begin{array}{l}\text { Global Climate } \\
\text { Legislation Study } \\
\& \\
\text { POLCLIMATE } \\
\text { data set }\end{array}$ & $\mathrm{H} 1$ \\
\hline & $\begin{array}{l}\text { Interaction } \\
\text { similarity }\end{array}$ & $\begin{array}{l}\text { Adoption behaviour of } \\
\text { structurally equivalent } \\
\text { actors }\end{array}$ & $\begin{array}{l}\text { Global Climate } \\
\text { Legislation Study } \\
\& \\
\text { POLCLIMATE } \\
\text { data set }\end{array}$ & $\mathrm{H} 2$ \\
\hline & Same region & $\begin{array}{l}\text { Regional proximity } \\
\text { captured as homophily } \\
\text { variable, i.e. whether } \\
\text { country } i \text { and } j \text { are located } \\
\text { in the same world region. }\end{array}$ & $\begin{array}{l}\text { Own coding } \\
\text { according to } \\
\text { World Bank } \\
\text { regions }\end{array}$ & $\begin{array}{l}\text { Control } \\
\text { variable }\end{array}$ \\
\hline
\end{tabular}




\section{Results}

We estimated the model in R using the 'tnam' package (Leifeld and Cranmer (2016) and the 'Imer' package (Bates et al. 2015). As our dependent variable is a count variable with the mean differing from the variance, we executed the temporal network autocorrelation model using a negative binomial distribution function. We include fixed effects to control for unobservable period-specific events that could affect our results.

We estimated the parameters with maximum-likelihood estimation, which is the standard estimation routine implemented in the 'Imer' package. We also scaled and centered all the variables used in the analysis to improve model convergence. Doing this also enhanced interpretability of the results. Table 4 presents the parameter estimates of our models with standard errors in parentheses. The results are presented as the direct coefficients. We started the analysis with a model that includes only internal determinants in Model 1. Model 2 is the classical version of the integrated diffusion model, including geographical proximity indicated by the same region homophily term. In Model 3, we take in the two network autocorrelation terms that capture the effect of political interactions on climate policy adoption alongside regional proximity. However, there is a high correlation between structural similarity and geographical proximity, which is why the effects are both not significant. This is hardly surprising as structurally similar countries are often located in the same region. In general, structural equivalence in this context contends that countries having similar background conditions will demonstrate a comparable political behavior. Therefore, we assume that countries that are structurally equivalent in terms of their cooperative interactions are also likely to share similar individual characteristics relevant to the climate change issue (e.g. vulnerability, wealth, per capita emissions, geographical location, etc.).

Therefore, in Model 4, we present a version of the integrated model with the two network autocorrelation terms but without the Same Region variable. The advantage of using political interactions to study diffusion is that they vary over time. This offers a much more precise estimation of country interdependencies than the time-invariant geographical proximity variable ${ }^{10}$. Furthermore, we present marginal effects for the significant model terms in Appendix E.

\footnotetext{
${ }^{10}$ In addition to these models, in Appendix D, we present a number of robustness checks. We estimated a number of models testing other covariates, variable combinations, interaction effects, and models using different time slices. Overall, our results are robust across these models.
} 
Table 4: Results Temporal Network Autocorrelation Model

\begin{tabular}{|c|c|c|c|c|}
\hline & $\begin{array}{l}\text { MODEL } 1 \\
\left(\mathrm{ADOPT}_{\mathrm{IT}}\right)\end{array}$ & $\begin{array}{l}\text { MODEL } 2 \\
\left(\mathrm{ADOPT}_{\mathrm{IT}}\right)\end{array}$ & $\begin{array}{l}\text { MODEL } 3 \\
\left(\mathrm{ADOPT}_{\mathrm{IT}}\right)\end{array}$ & $\begin{array}{l}\text { MODEL } 4 \\
\left(\text { ADOPT }_{I T}\right)\end{array}$ \\
\hline INTERCEPT & $\begin{array}{c}0.37 \\
(0.34)\end{array}$ & $\begin{array}{l}0.29 * * * \\
(0.07)\end{array}$ & $\begin{array}{l}0.29 * * * \\
(0.07)\end{array}$ & $\begin{array}{l}0.30 * * * \\
(0.07)\end{array}$ \\
\hline \multicolumn{5}{|l|}{ INTERNAL DETERMINANTS (INT/T) } \\
\hline \multicolumn{5}{|l|}{ MOTIVATION (M $\left.\mathrm{M}_{\mathrm{T}}\right)$} \\
\hline FOSSIL FUEL CONSUMPTION & $\begin{array}{c}0.12 \\
(0.08)\end{array}$ & $\begin{array}{c}0.11 \\
(0.08)\end{array}$ & $\begin{array}{c}0.12 \\
(0.08)\end{array}$ & $\begin{array}{c}0.13 \\
(0.08)\end{array}$ \\
\hline CO2 PER CAPITA & $\begin{array}{l}-0.21 * \\
(0.09)\end{array}$ & $\begin{array}{l}-0.22 * \\
(0.09)\end{array}$ & $\begin{array}{l}-0.21 * \\
(0.09)\end{array}$ & $\begin{array}{l}-0.18 * \\
(0.09)\end{array}$ \\
\hline POPULATION (LOGGED) & $\begin{array}{l}0.40 * * * \\
(0.70)\end{array}$ & $\begin{array}{l}0.40 * * * \\
(0.07)\end{array}$ & $\begin{array}{l}0.39 * * * \\
(0.07)\end{array}$ & $\begin{array}{l}0.40 * * * \\
(0.07)\end{array}$ \\
\hline LEFT GOVERNMENT & $\begin{array}{c}0.08 \\
(0.06)\end{array}$ & $\begin{array}{c}0.07 \\
(0.06)\end{array}$ & $\begin{array}{c}0.06 \\
(0.06)\end{array}$ & $\begin{array}{c}0.09 \\
(0.06)\end{array}$ \\
\hline VULNERABILITY & $\begin{array}{c}0.00 \\
(0.11)\end{array}$ & $\begin{array}{l}-0.02 \\
(0.11)\end{array}$ & $\begin{array}{c}0.00 \\
(0.11)\end{array}$ & $\begin{array}{c}0.00 \\
(0.11)\end{array}$ \\
\hline \multicolumn{5}{|l|}{ RESOURCES $\left(R_{I T}\right)$} \\
\hline GDP PER CAPITA (LOGGED) & $\begin{array}{c}0.20 \\
(0.14) \\
\end{array}$ & $\begin{array}{c}0.22 \\
(0.14) \\
\end{array}$ & $\begin{array}{c}0.22 \\
(0.14) \\
\end{array}$ & $\begin{array}{c}0.20 \\
(0.14) \\
\end{array}$ \\
\hline DEMOCRACY STATUS (POLITY2) & $\begin{array}{l}0.26 * * * \\
(0.07)\end{array}$ & $\begin{array}{l}0.26^{* * *} \\
(0.07)\end{array}$ & $\begin{array}{l}0.26^{* * *} \\
(0.07)\end{array}$ & $\begin{array}{l}0.28^{* * *} \\
(0.07)\end{array}$ \\
\hline \multicolumn{5}{|l|}{ EXISTING POLICIES (ADOPT $\left.T_{I T-1}\right)$} \\
\hline PAST POLICY ADOPTION & $\begin{array}{c}0.00 \\
(0.05)\end{array}$ & $\begin{array}{c}0.00 \\
(0.05)\end{array}$ & $\begin{array}{c}0.01 \\
(0.05)\end{array}$ & $\begin{array}{l}-0.01 \\
(0.05)\end{array}$ \\
\hline \multicolumn{5}{|l|}{ EXTERNAL DETERMINANTS } \\
\hline SAME REGION (PROXI) & & $\begin{array}{l}0.53 * * * \\
(0.05)\end{array}$ & $\begin{array}{l}0.52 * * \\
(0.18)\end{array}$ & \\
\hline \multicolumn{5}{|l|}{ NETWORK AUTOCORRELATION } \\
\hline INTERACTION SIMILARITY & & & $\begin{array}{l}-0.02 \\
(0.18)\end{array}$ & $\begin{array}{l}0.47^{* * *} \\
(0.05)\end{array}$ \\
\hline COOPERATIVE INTERACTION & & & $\begin{array}{c}0.05 \\
(0.05)\end{array}$ & $\begin{array}{c}0.11 * \\
(0.04)\end{array}$ \\
\hline AIC & 912.18 & 904.11 & 906.83 & 912.57 \\
\hline $\mathrm{BIC}$ & 951.76 & 947.29 & 957.21 & 959.35 \\
\hline LOG LIKELIHOOD & -445.09 & -440.05 & -439.41 & -443.29 \\
\hline NUM. OBS. & 270 & 270 & 270 & 270 \\
\hline NUM. GROUPS & 3 & 3 & 3 & 3 \\
\hline TIME FIXED EFFECTS & yes & yes & yes & yes \\
\hline NOTES & $\begin{array}{l}\left(\mathrm{P}<0.001^{* * *}\right. \\
\text { STANDARD ER }\end{array}$ & $\begin{array}{l}0.01^{* *}, \mathrm{P}<0 . \\
\text { IN PARENTHES }\end{array}$ & & \\
\hline
\end{tabular}

Comparing across the models shows, as suggested in our first hypothesis, that cooperative interactions in the form of an exchange of resources, personal interactions, and knowledge transfer increases the likelihood for adopting climate policies. Repeated cooperation fosters 
trust and triggers mutual learning, which reduces the likelihood of a free-riding behavior and increases the propensity for coordinated action in the context of climate change mitigation. Hypothesis 2 states that actors that are structurally equivalent, i.e. they show a similar interaction behavior, to countries that adopt a high number of climate policies, are significantly more likely to adopt climate policies. Being similarly embedded in the international context, therefore, seems to cause comparable incentives for adopting climate policies, thereby leading to similar policy adoption behavior. On the one hand, these countries possibly compare with each other triggering policy learning. On the other hand, other countries set benchmarks for their own behavior in a positive as well as a negative sense. In the case of climate policy, countries fear competitive disadvantages from adopting national policies. This may cause them not to surpass others in their engagement of the mitigation of climate change. Conversely, if others are particularly active with regard to climate change mitigation, social pressure might increase the need to adopt more policies. Overall, these results provide evidence for both of our hypotheses.

With respect to our control variables, the results show that countries with higher GDP per capita do not adopt more mitigation policies. One possible explanation is that in many rich countries, climate-related laws are already in place rendering the need for further legislation unnecessary. Results of the Global Climate Legislation study (Nachmany et al. 2014) supports this consideration and show that the most recent growth of climate policies has predominantly taken place in the developing world. For the Polity 2 model term, we find a positive effect for the parameter estimate, which is highly consistent with the earlier literature on the effect of democracy on climate policy (Bättig, Bernauer 2009; Bernauer 2013). Furthermore, there is no significant effect of the level of fossil fuel consumption. But, the effect is robust and consistent across all models. Moreover, we find that the population parameter is positively significant and robust across all the models, implying that ceteris paribus, more populated countries adopt more policies. These countries are usually also those with the highest absolute values of $\mathrm{CO}_{2}$ emissions. Both aspects, the level of fossil fuel consumption and emissions, trigger national policies to prevent pollution or decrease the dependency on fossil resources. Co-benefits that arise from these policies such as the reduction of local air pollution, increased energy efficiency, and so on are an additional explanation. Moreover, big polluters are under immense international pressure to act and adopt effective climate legislation. In contrast, the results also show that countries with high per capita $\mathrm{CO}_{2}$ emissions adopt fewer policies than those countries with lower per capita emissions. We argue that countries with high levels per capita emissions, like the oil-exporting countries of the Middle 
East, have far less incentives to reduce their emissions as their economies strongly depend on fossil energy sources. Moreover, as expected we do not find significant effects for the vulnerability of a country. We also do not find any effect of political partisanship of a country. Also, the model shows no effect related to the number of climate policies adopted in the past. Finally, for the same region variable, we find a positive and significant effect, which confirms the findings of many earlier diffusion studies claiming that policies diffuse across geographically close countries. 


\section{Concluding Comments}

In this article, we demonstrate how international interactions can influence national mitigation policy adoption. Aligning with other contributions (e.g. Mohrenberg 2017), our research highlights the added value of integrating a dynamic social network perspective in the climate policy diffusion literature. Our analysis establishes that accounting for temporal network dependencies enriches analytical frameworks such as the 'unified model of government innovation' (Berry, Berry 2014) in their explanatory power. Political interactions between countries from bi- or multilateral political events reflect international relations in a more overarching way than the traditional approaches of the diffusion literature, which rely on spatial approaches to operationalize interdependencies. This is of in particular relevance for global issue areas, such as climate change policy.

In this context, we proposed a dynamic network analysis of political interactions between country pairs, using a subset of 98 countries and the European Union to reveal general patterns connected to the adoption and diffusion of national mitigation policies in the past two decades. To the best of our knowledge, this is the first approach that uses political interactions as a proxy for interdependencies in the climate policy realm. The most crucial advantage of this approach is that it accounts for changing political circumstances, by operationalizing these changing international relations. Internal determinants, like the motivation and resources of a country to tackle climate change, are undoubtedly significant aspects of climate policy adoption. Different countries may be incentivized in differing degrees to implement climate protection measures, on account of specific national circumstances. Examples of national characteristics affecting the likelihood of adopting climate policies may be the prevailing energy mix of a country, its vulnerability towards climate change, or the strength of environmental organizations. However, these internal factors, as long as they do not vary over time, are not sufficient to explain the changes in the policy adoption behavior of a country. In addition, the diffusion of policies characterizes a relational process. To gather an accurate understanding of diffusion, a time as well as network perspective is indispensable. Our results underline this argument, as they clearly show that the propensity of a country to adopt climate change mitigation policies rises if it repeatedly engages in cooperative interactions with, or is structurally equivalent to, a country that has implemented comparable policies.

This research has vital implications for the climate change literature more specifically. In line with Jordan et al. (2015), it highlights the importance of a polycentric perspective on the 'small but positive steps' (Ostrom 2012, p. 353) that are underway at the national and local 
scale to combat climate change. Countries cooperate if they disagree over important contestations to align their positions in the international climate negotiations and to coordinate national climate protection measures. As a result, countries are more likely to adopt similar policies at the national level if they are increasingly cooperating with each other. If governments regularly exchange information about their programs, negotiate activities, or settle disputes, they develop reliable relationships. In turn, these relationships exert influence on each other through a process of communication and comparison. Even in the absence of these close relationships, national governments must consider the policy positions and activities of other countries. In a policy domain, prone to free-riding, ambitious solo runs can be costly due to relative losses and competitive disadvantages. Contrariwise, ambitious initiatives from other actors, especially if they are in similar structural positions, may increase the social pressure to emulate social norms. This creates an incentive to implement policies.

In addition, the paper demonstrates that countries implement more national climate policies if they cooperate with other countries that also adopt climate protection measures. If a country learns that other countries comply with the international climate protection regime, they are more likely to comply themselves. Repeated and reciprocated interaction between countries reduces free-riding behavior, due to the increased social control in the absence of powerful sanction mechanisms. Also, the international process creates awareness of the climate problem among governments and the general public. It is, therefore, increasingly difficult to diminish. In this process of continuous interaction, countries also compare with each other to understand what they do in terms of climate policy, especially when they share similar backgrounds. Moreover, direct interactions create a channel for communication and policy learning. The international climate regime facilitates all these processes by creating a common forum for regular meetings and negotiations, dealing with disputes, exchanging information, and so on. Therefore, even if climate negotiations fail to deliver effective agreements, they create a forum that fosters cooperation among countries and increases the likelihood for the adoption of climate policies.

However, we do acknowledge our study has some drawbacks related to the data used. To begin with, the data on climate change related mitigation legislation from the Global Climate Legislation Study did not include sub-national laws or amendments to the current laws and this could have led to a valuable loss of observations. Moreover, the analysis might have profited from a qualitative differentiation between different climate mitigation policies, such as framework legislation vs. sectoral policies, different sectors, or even policy design-related aspects. This might have helped us understand more about what kind of policies or policy 
instruments are more likely to diffuse. For future research, we suggest extending our approach by differentiating policies with respect to their outreach (e.g. sector-specific vs. flagship laws). A more nuance integration of policies possibly improves the model of the diffusion processes, by avoiding an underestimation of comprehensive legislation. Alternatively, a further area of research could be directed towards a more policy designoriented perspective that studies the mechanisms behind the diffusion of sectoral-specific legislation or policy instruments.

Additionally, the use of event data is not without complications. The most common threats to validity (Schrodt, Gerner 1994; Hirschi 2009) in event data coding are biases introduced by the choice of media sources. Furthermore, coding scheme or coding process may also lead to biases. The source-related validity issues mostly arise in the course of the editorial selection process. For example, it may arise when conflictive events dominate the reporting (conflict orientation), or when media attention towards a specific issue decreases (media fatigue), or due to the duplicate stories that emerge when multiple reports on the same event are published by numerous media sources or repeated in different reports. We tried reducing these validity issues by using the electronic wire services Agence France Presse, as editorial choices affect them less than other journalistic sources like newspapers (Schrodt 2012). An integration of other wire services from other countries might improve the validity of the dataset by increasing the number observations. Finally, we restrict the present study to cooperative interactions only and do not distinguish between different intensities of cooperation. Therefore, a possible follow-up project could work towards refining the policy networks and testing for various types of interaction that may also include conflictive events. 


\section{Publication bibliography}

Abbott, Andrew; DeViney, Stanley (1992): The Welfare State as Transnational Event: Evidence from Sequences of Policy Adoption. In Soc. sci. hist. 16 (02), pp. 245-274. DOI:

10.1017/S0145553200016473.

Bates, Douglas; Mächler, Martin; Bolker, Ben; Walker, Steve (2015): Fitting Linear Mixed-Effects Models Using Ime4. In J. Stat. Soft. 67 (1). DOI: 10.18637/jss.v067.i01.

Bättig, Michèle B.; Bernauer, Thomas (2009): National Institutions and Global Public Goods. Are Democracies More Cooperative in Climate Change Policy? In International Organization 63 (02), pp. 281-308. DOI: 10.1017/\$0020818309090092.

Beck, Nathaniel; Gleditsch, Kristian Skrede; Beardsley, Kyle (2006): Space is more than Geography: Using Spatial Econometrics in the Study of Political Economy. In International Studies Quarterly 50, pp. 27-44.

Bennett, Colin J. (1991): What Is Policy Convergence and What Causes It? In Brit. J. Polit. Sci. 21 (02), p. 215. DOI: 10.1017/S0007123400006116.

Bernauer, Thomas (2013): Climate Change Politics. In Annual Review of Political Science 16, pp. $421-$ 448.

Bernstein, Steven; Cashore, Benjamin (2012): Complex Global Governance and Domestic Policies. Four Pathways of Influence. In International Affairs 88 (3), pp. 585-604. DOI: 10.1111/j.14682346.2012.01090.x.

Berry, Frances Stokes; Berry, William D. (1990): State Lottery Adoptions as Policy Innovations. An Event History Analysis. In The American Political Science Review 84 (2), pp. 395-415. DOI: 10.2307/1963526.

Berry, Frances Stokes; Berry, William D. (2007): Innovation and Diffusion Models in Policy Research. In Paul Sabatier (Ed.): Theories of the Policy Process. Boulder: Westview Press.

Berry, Frances Stokes; Berry, William D. (2014): Innovation and Diffusion Models in Policy Research. In Paul A. Sabatier, Christopher M. Weible (Eds.): Theories of the policy process. Third Edition. Boulder, Colo.: Westview Press, pp. 307-362. 
Biesenbender, Sophie; Tosun, Jale (2014): Domestic politics and the diffusion of international policy innovations. How does accommodation happen? In Global Environmental Change 29, pp. 424-433. DOI: 10.1016/j.gloenvcha.2014.04.001.

Braun, Dietmar; Gilardi, Fabrizio (2006): Taking 'Galton's Problem' Seriously. In Journal of Theoretical Politics 18 (3), pp. 298-322. DOI: 10.1177/0951629806064351.

Canon, Bradley C.; Baum, Lawrence (1981): Patterns of Adoption of Tort Law Innovations: An Application of Diffusion Theory to Judicial Doctrines. In American Political Science Review 75 (04), pp. 975-987. DOI: 10.2307/1962297.

Chyzh, Olga (2016): Dangerous liaisons. In Journal of Peace Research 53 (3), pp. 409-423. DOI: 10.1177/0022343316629605.

Clémençon, Raymond (2016): The Two Sides of the Paris Climate Agreement. In The Journal of Environment \& Development 25 (1), pp. 3-24. DOI: 10.1177/1070496516631362.

Dimitrov, Radoslav (2010): Inside Copenhagen. The State of Climate Governance. In Global Environmental Politics 10 (2), pp. 18-24.

Dolšak, Nives (2001): Mitigating Global Climate Change: Why Are Some Countries More Committed Than Others? In Policy Studies Journal 29 (3), pp. 414-436. DOI: 10.1111/j.1541-0072.2001.tb02102.x. Dolšak, Nives (2009): Climate Change Policy Implementation. A Cross-Sectional Analysis. In Review of Policy Research 26 (5), pp. 551-570.

Dolšak, Nives (2013): Climate Change Policies in the Transitional Economies of Europe and Eurasia. The Role of NGOs. In Voluntas 24 (2), pp. 382-402. DOI: 10.1007/s11266-012-9260-6.

Dorussen, Han; Ward, Hugh (2010): Trade networks and the Kantian peace. In Journal of Peace Research 47 (1), pp. 29-42. DOI: 10.1177/0022343309350011.

Du Robiou Pont, Yann; Jeffery, M. Louise; Gütschow, Johannes; Rogelj, Joeri; Christoff, Peter; Meinshausen, Malte (2017): Equitable mitigation to achieve the Paris Agreement goals. In Nature Climate change 7 (1), pp. 38-43. DOI: 10.1038/nclimate3186.

Dunlap, Riley E.; McCright, Aaron M.; Yarosh, Jerrod H. (2016): The Political Divide on Climate Change: Partisan Polarization Widens in the U.S. In Environment: Science and Policy for Sustainable Development 58 (5), pp. 4-23. DOI: 10.1080/00139157.2016.1208995. 
Eisenack, Klaus; Edenhofer, Ottmar; Kalkuhl, Matthias (2012): Resource rents. The effects of energy taxes and quantity instruments for climate protection. In Energy Policy 48, pp. 159-166. DOI: 10.1016/j.enpol.2012.05.001.

Elkins, Zachary; Simmons, Beth (2005): On Waves, Clusters, and Diffusion. A Conceptual Framework. In The ANNALS of the American Academy of Political and Social Science 598 (1), pp. 33-51. DOI: 10.1177/0002716204272516.

Fankhauser, Sam; Gennaioli, Caterina; Collins, Murray (2014): Domestic Dynamics and International Influence: What Explains the Passage of Climate Change Legislation. Centre for Climate Change Economics and Policy (Working Paper No. 175). Available online at http://www.Ise.ac.uk/GranthamInstitute/wp-content/uploads/2014/05/Wp156-Domestic-dynamicsand-international-influence-what-explains-the-passage-of-climate-change-legislation.pdf.

Franzese, Robert J.; Hays, Jude C. (2007): Spatial Econometric Models of Cross-Sectional Interdependence in Political Science Panel and Time-Series-Cross-Section Data. In Polit. anal. 15 (02), pp. 140-164. DOI: 10.1093/pan/mpm005.

Gilardi, Fabrizio (2005): The Institutional Foundations of Regulatory Capitalism: The Diffusion of Independent Regulatory Agencies in Western Europe. In The ANNALS of the American Academy of Political and Social Science 598 (1), pp. 84-101. DOI: 10.1177/0002716204271833.

Gilardi, Fabrizio (2010): Who Learns from What in Policy Diffusion Processes? In American Journal of Political Science 54 (3), pp. 650-666.

Gilardi, Fabrizio (2012): Transnational diffusion. Norms, ideas, and policies. In Thomas Risse, Beth Simmons (Eds.): Handbook of International Relations, 453-477. Thousand Oaks: SAGE Publications.

Gilardi, Fabrizio; Füglister, Katharina (2008): Empirical Modeling of Policy Diffusion in Federal States. The Dyadic Approach. In Swiss Political Science Review 14 (3), pp. 413-450.

Graham, Charles R.; Woodfield, Wendy; Harrison, J. Buckley (2013): A framework for institutional adoption and implementation of blended learning in higher education. In The Internet and Higher Education 18, pp. 4-14. DOI: 10.1016/j.iheduc.2012.09.003.

Grantham Research Institute, London School of Economics (2016): Global Climate Legislation database. Available online at http://www.Ise.ac.uk/GranthamInstitute/Legislation, checked on $12 / 28 / 2016$. 
Gray, Virginia (1973): Innovation in the States: A Diffusion Study. In American Political Science Rev 67 (04), pp. 1174-1185. DOI: 10.2307/1956539.

Haim, Dotan A. (2016): Alliance networks and trade. In Journal of Peace Research 53 (3), pp. 472-490. DOI: $10.1177 / 0022343316630938$.

Hardin, Garrett (1968): The Tragedy of the Commons. In Science 162 (3859), pp. 1243-1248. DOI: 10.1126/science.162.3859.1243.

Hasson, Reviva; Löfgren, Åsa; Visser, Martine (2010): Climate change in a public goods game: Investment decision in mitigation versus adaptation. In Ecological Economics 70 (2), pp. 331-338. DOI: 10.1016/j.ecolecon.2010.09.004.

Hirschi, Christian (2008): Event Data Analysis Applied to Environmental Policy. In. 104th Annual Meeting of the American Political Science Association. Boston, MA, 28 - 31 August 2008.

Hirschi, Christian (2009): Intervening Against Apartheid. The South Africa Policy of the United States, West Germany, Sweden and Switzerland, 1977-1996. Zürich, University of, Zürich.

Holzinger, Katharina; Knill, Christoph (2005): Causes and conditions of cross-national policy convergence. In Journal of European Public Policy 12 (5), pp. 775-796. DOI: 10.1080/13501760500161357.

IPCC (2007): Climate Change 2007. Synthesis Report. Contributions of Working Groups I, II, and III to the Fourth Assessment Report of the Intergovernmental Panel on Climate Change [Core Writing Team, Pachauri, R.K and Reisinger, A. (Eds.)]. Geneva, Switzerland.

Jänicke, Martin (2005): Trend-setters in environmental policy: the character and role of pioneer countries. In European Environment. 15 (2), pp. 129-142. DOI: 10.1002/eet.375.

Jordan, Andrew; Wurzel, Rüdiger; Zito, Anthony R.; Brückner, Lars (2005): European Govnernance and the Transfer of 'New' Environmental Policy Instruments (NEPIs) in the European Union. In Andrew Jordan (Ed.): Environmental policy in the European Union. Actors, institutions, and processes. $2^{\text {nd }}$ ed. Sterling, VA: Earthscan, pp. 317-335.

Jordan, Andrew J.; Huitema, Dave; Hildén, Mikael; van Asselt, Harro; Rayner, Tim J.; Schoenefeld, Jonas J. et al. (2015): Emergence of polycentric climate governance and its future prospects. In Nature Climate change 5 (11), pp. 977-982. DOI: 10.1038/NCLIMATE2725. 
Kammerer, Marlene \& Hirschi, Christian (2015): Policy Networks and Belief Systems. The Drivers of Cooperation in International Climate Change Politics 2001-2014, Conference Proceeding, MPSA Chicago, April 2015.

Karch, Andrew (2007): Emerging Issues and Future Directions in State Policy Diffusion Research. In State Politics \& Policy Quarterly 7 (1), pp. 54-80. DOI: 10.1177/153244000700700104.

Keohane, Robert Owen (1984): After hegemony. Cooperation and discord in the world political economy. N.J: Princeton University Press

Kern, Kristine; Jörgens, Helge; Jänicke, Martin (2001): The Diffusion of Environmental Policy Innovations: A Contribution to the Globalisation of Environmental Policy. Wissenschaftszentrum Berlin für Sozialforschung. Berlin (Discussion Paper FS II 01 - 302).

Knill, Christoph; Liefferink, Duncan (2007): Environmental politics in the European Union. Policymaking, implementation and patterns of multi-level governance. Manchester, UK, New York, N.Y: Manchester Univ Press Palgrave.

Knill, Christoph; Shikano, Susumu; Tosun, Jale (2014): Explaining Environmental Policy Adoption: A Comparative Analysis of Policy Developments in Twenty-Four OECD Countries. In Andreas Duit (Ed.): State and environment. The comparative study of environmental governance. Cambridge, Mass: MIT Press (American and comparative environmental policy), pp. 53-80.

Leenders, Roger (2002): Modeling social influence through network autocorrelation. Constructing the weight matrix. In Social Networks 24 (1), pp. 21-47. DOI: 10.1016/S0378-8733(01)00049-1.

Leifeld, Philip; Cranmer, Skyler J. (2016): Temporal and cross-sectional network autocorrelation models (TNAM). Available online at ftp://cran.r-project.org/pub/R/web/packages/tnam/tnam.pdf, checked on 12/30/2016.

Liefferink, Duncan; Arts, Bas; Kamstra, Jelmer; Ooijevaar, Jeroen (2009): Leaders and laggards in environmental policy: a quantitative analysis of domestic policy outputs. In Journal of European Public Policy 16 (5), pp. 677-700. DOI: 10.1080/13501760902983283.

Madden, Nathan J. (2014): Green means stop: veto players and their impact on climate-change policy outputs. In Environmental Politics 23 (4), pp. 570-589. DOI: 10.1080/09644016.2014.884301. 
Maoz, Zeev; Kuperman, Ranan D.; Terris, Lesley; Talmud, Ilan (2006): Structural Equivalence and International Conflict. A Social Networks Analysis. In Journal of Conflict Resolution 50 (5), pp. 664-689. DOI: $10.1177 / 0022002706291053$.

Marin, Alexandra; Wellman, Barry (2011): Social Network Analysis: An Introduction. In John Scott, Peter J. Carrington (Eds.): The Sage Handbook of Social Network Analysis. London, Thousand Oaks.

Massey, Eric; Biesbroek, Robbert; Huitema, Dave; Jordan, Andy (2014): Climate policy innovation: The adoption and diffusion of adaptation policies across Europe. In Global Environmental Change 29, pp. 434-443. DOI: 10.1016/j.gloenvcha.2014.09.002.

Matisoff, Daniel C. (2008): The Adoption of State Climate Change Policies and Renewable Portfolio Standards. Regional Diffusion or Internal Determinants? In Review of Policy Research 25 (6), pp. 527546. DOI: 10.1111/j.1541-1338.2008.00360.x.

Matisoff, Daniel C.; Edwards, Jason (2014): Kindred spirits or intergovernmental competition? The innovation and diffusion of energy policies in the American states (1990-2008). In Environmental Politics 23 (5), pp. 795-817. DOI: 10.1080/09644016.2014.923639.

Meseguer, Covadonga; Gilardi, Fabrizio (2009): What is new in the study of policy diffusion? In Review of International Political Economy 16 (3), pp. 527-543. DOI: 10.1080/09692290802409236.

Mohrenberg, Steffen (2017): Studying Policy Diffusion with Stochastic Actor-Oriented Models. In Betina Hollstein, Wenzel Matiaske, Kai-Uwe Schnapp (Eds.): Networked Governance. New Research Perspectives. Cham, s.I.: Springer International Publishing, pp. 163-188.

Mozumder, Pallab; Flugman, Evan; Randhir, Timothy (2011): Adaptation behavior in the face of global climate change: Survey responses from experts and decision makers serving the Florida Keys. In Ocean \& Coastal Management 54 (1), pp. 37-44. DOI: 10.1016/j.ocecoaman.2010.10.008.

Nachmany, M.; Fankhauser, Sam; Townshend, T.; Collins, Murray; Landesman, T.; Matthews, A. et al. (2014): The GLOBE Climate Legislation Study: A Review of Climate Change Legislation in 66 Countries. Fourth Edition. GLOBE International and Grantham Research Institute, London School of Economics. London.

Neumayer, Eric (2002): Do Democracies Exhibit Stronger International Environmental Commitment? A Cross-country Analysis. In Journal of Peace Research 39 (2), pp. 139-164. DOI:

$10.1177 / 0022343302039002001$ 
Neumayer, Eric (2003): Are left-wing party strength and corporatism good for the environment? Evidence from panel analysis of air pollution in OECD countries. In Ecological Economics 45 (2), pp. 203-220. DOI: 10.1016/S0921-8009(03)00012-0.

Neumayer, Eric; Plümper, Thomas (2016): W. In PSRM 4 (01), pp. 175-193. DOI:

10.1017/psrm.2014.40.

Oberthür, Sebastian; Tänzer, Dennis (2002): International Regimes as a Trigger of Policy Diffusion: The Development of Climate Policies in the European Union. In Frank Biermann, Rainer Brohm, Klaus Dingwerth (Eds.): Proceedings of the 2001 Berlin Conferene on the Human Dimensions of Global Environmental Change. Global Environmental Change and the Nation Sate (PIK Report, 80), pp. 317328.

Ostrom, Elinor (2012): Nested externalities and polycentric institutions: must we wait for global solutions to climate change before taking actions at other scales? In Econ Theory 49 (2), pp. 353-369. DOI: 10.1007/s00199-010-0558-6.

Plümper, Thomas; Schneider, Christina J. (2009): The analysis of policy convergence, or: how to chase a black cat in a dark room. In Journal of European Public Policy 16 (7), pp. 990-1011. DOI:

$10.1080 / 13501760903226724$.

Regens, James L. (1980): State Policy Responses to the Energy Issue: An Analysis of Innovation. In Social Science Quarterly 61 (1), pp. 44-57.

Rogers, Everett Mitchell (1983): Diffusion of innovations. New York: Free Press.

Schrodt, Philip A. (2012): Precedents, Progress, and Prospects in Political Event Data. In International Interactions 38 (4), pp. 546-569. DOI: 10.1080/03050629.2012.697430.

Schrodt, Philip A.; Gerner, Deborah J. (1994): Validity Assessment of a Machine-Coded Event Data Set for the Middle East, 1982-92. In American Journal of Political Science 38 (3), pp. 825-854. DOI: 10.2307/2111609.

Simmons, Beth A.; Elkins, Zachary (2004): The Globalization of Liberalization. Policy Diffusion in the International Political Economy. In APSR 98 (01), pp. 171-189. DOI: 10.1017/S0003055404001078.

Spash, Clive L. (2016): This Changes Nothing: The Paris Agreement to Ignore Reality. In Globalizations 13 (6), pp. 928-933. DOI: 10.1080/14747731.2016.1161119. 
Teorell, Jan; Dahlberg, Stefan; Holmberg, Sören; Rothstein, Bo; Alvarado Pachon, Natalia; Svensson, Richard (2018): QoG Standard Dataset 2018.

The World Bank (2017): World Development Indicators. 2017. Available online at https://datacatalog.worldbank.org/dataset/world-development-indicators, checked on 5/7/2018.

Thurston, George D. (2013): Mitigation policy. Health co-benefits. In Nature Climate change 3 (10), pp. 863-864. DOI: 10.1038/nclimate2013.

Tobin, Paul (2017): Leaders and Laggards: Climate Policy Ambition in Developed States. In Global Environmental Politics 17 (4), pp. 28-47. DOI: 10.1162/GLEP_a_00433.

Tol, Richard S. J.; Klein, Richard J. T.; Nicholls, Robert J. (2008): Towards Successful Adaptation to SeaLevel Rise along Europe's Coasts. In Journal of Coastal Research 242, pp. 432-442. DOI: 10.2112/07A0016.1.

True, Jacqui; Mintrom, Michael (2001): Transnational Networks and Policy Diffusion: The Case of Gender Mainstreaming. In International Studies Quarterly 45 (1), pp. 27-57.

Tubi, Amit; Fischhendler, Itay; Feitelson, Eran (2012): The effect of vulnerability on climate change mitigation policies. In Global Environmental Change 22 (2), pp. 472-482. DOI: 10.1016/j.gloenvcha.2012.02.004.

Valente, Thomas (1996): Social network thresholds in the diffusion of innovations. In Social Networks 18, pp. 69-89.

Volden, Craig; Ting, Michael M.; Carpenter, Daniel P. (2008): A Formal Model of Learning and Policy Diffusion. In American Political Science Review 102 (3), pp. 319-332.

Wasserman, Stanley; Faust, Katherine (1994): Social Network Analysis. Methods and Applications. Cambridge: Cambridge University Press.

Wejnert, Barbara (2002): Integrating Models of Diffusion of Innovations: A Conceptual Framework. In Annual Review of Sociology. 28 (1), pp. 297-326. DOI: 10.1146/annurev.soc.28.110601.141051.

Wurzel, Rüdiger; Connelly, James (Eds.) (2011): The European Union as a leader in international climate change politics. Workshop. London: Routledge. 